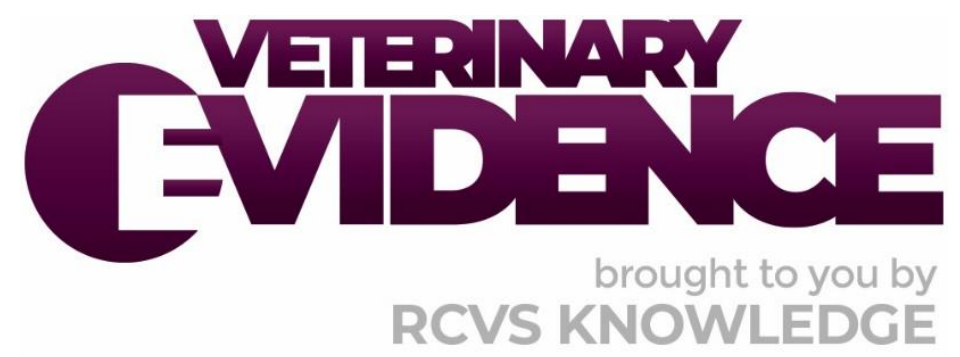

\title{
In canine cranial cruciate ligament rupture is outcome following TPLO improved compared with lateral suture?
}

\section{A Knowledge Summary by}

Catrina Pennington BVM\&S, MRCVS ${ }^{*}$

Ben Walton BVSC, DSAS (Orth), MRCVS, RCVS Specialist in Small Animal Surgery (Orthopaedics) ${ }^{2}$

Mark Morton BVSC, DSAS (Orth), MRCVS, RCVS Specialist in Small Animal Surgery (Orthopaedics)2

\footnotetext{
${ }^{1}$ The University of Edinburgh, Old College, South Bridge, Edinburgh EH8 9YL

${ }^{2}$ Chestergates Veterinary Specialists, E \& F, Telford Court, Chestergates Road, Chester CH1 6LT

*Corresponding Author (trinpennington@gmail.com)
}

ISSN: 2396-9776

Published: 20 Sep 2019

in: Vol 4, Issue 3

DOI: https://doi.org/10.18849/ve.v4i3.213

Reviewed by: Duncan Michael Barnes (MA, VetMB, DSAS (Orth), MRCVS, RCVS Recognised Specialist in Small Animal Surgery Orthopaedics) and Nina R Kieves (DVM, DACVS, DACVSMR, CCRT)

Next Review Date: May 31 2020 


\section{PICO question}

In dogs over $15 \mathrm{~kg}$, with cranial cruciate ligament rupture is there evidence of improved outcome following tibial plateau levelling osteotomy or lateral fabellotibial suture?

\section{Clinical bottom line}

Although the evidence is not conclusive, the literature reviewed here suggests that tibial plateau levelling osteotomy (TPLO) results in superior limb function and owner satisfaction compared to placement of a lateral fabellotibial suture (LFS).

There is currently insufficient evidence to determine if there is a difference in complication rates or osteoarthritis (OA) development following TPLO or LFS.

\section{Clinical Scenario}

A 7-year-old male neutered crossbreed dog, weighing $23 \mathrm{~kg}$ presents with an acute history of unilateral hind-limb lameness. On clinical examination pain is localised to the stifle joint. Radiography of the affected joint demonstrates the presence of increased soft tissue opacity suggestive of stifle effusion. At examination under sedation both cranial drawer and tibial compression tests are positive and a diagnosis of cranial cruciate ligament $(\mathrm{CCL})$ rupture is made.

You discuss surgical treatment options with the client. Both TPLO and LFS placement are performed locally and are financially feasible, other techniques are not available within a distance that the client is willing to travel and so are not considered.

When considering postoperative limb function, owner satisfaction and complication rates, what evidence is there to suggest a TPLO technique is superior to LFS placement (or vice versa)?

\section{Summary of the evidence}

\section{Abbreviations:}

CCL - Cranial cruciate ligament

TPLO - Tibial plateau levelling osteotomy

LFS - Lateral fabellotibial suture

NSAID - Nonsteroidal anti-inflammatory drugs

OA - Osteoarthritis

TTA - Tibial tuberosity advancement

Molsa et al. (2014)

Population: Treatment group: Dogs over $17 \mathrm{~kg}$ bodyweight, of various breeds and crossbreeds, with naturally occurring, unilateral CCL rupture treated surgically with various

methods at least 1.5 years prior to follow up evaluation. Age range was $6.9 \pm 2.7$ years.

Weight range was $38.2 \pm 9.5 \mathrm{~kg}$. 


\begin{tabular}{|c|c|}
\hline & $\begin{array}{l}\text { Animals were excluded if they had evidence of concomitant stifle joint disease, or } \\
\text { other significant orthopaedic or neurological concerns as reported by their owner. } \\
\text { Control group: Clinically healthy Rottweilers and Labradors, between } 1 \text { and } 8 \text { years of } \\
\text { age, with no known orthopaedic disease and radiographically free of elbow and hip } \\
\text { dysplasia according to the Federation Cynologique Internationale screening protocol. }\end{array}$ \\
\hline Sample size: & $\begin{array}{l}\text { Treatment group: } 47 \text { dogs } \\
\text { Control group: } 21 \text { dogs } \\
\text { Dogs were recruited from six individual referral practices }\end{array}$ \\
\hline $\begin{array}{r}\text { Intervention } \\
\text { details: }\end{array}$ & $\begin{array}{l}\text { Owners were invited to enroll their dogs in the study based on a previous } \\
\text { questionnaire study (Molsa et al. 2013) and unpublished questionnaire data. } \\
\text { Seven dogs received LFS, } 19 \text { dogs received a modified intracapsular suture repair, nine } \\
\text { dogs received a TPLO, seven received a tibial tuberosity advancement and five dogs } \\
\text { received a triple tibial osteotomy. } \\
\text { Two subgroups were formed; } \\
\text { - Subgroup } 1 \text { dogs had no other signs of orthopaedic disease ( } 21 \text { dogs) } \\
\quad \text { Force plate, static weight bearing, active range of motion, goniometry } \\
\quad \text { and muscle atrophy results were evaluated. } \\
\text { or tarsus ( } 33 \text { dogs) } \\
\quad \quad \text { Goniometry results only were evaluated. } \\
\text { Force plate analysis and physiotherapeutic evaluation were performed in the control } \\
\text { group to allow comparison with treated groups. } \\
\text { NSAIDs, opioids, short-term corticosteroid pain medication, and nutraceutical } \\
\text { medication were withdrawn at a minimum of } 7 \text { days, long-term corticosteroids } 30 \\
\text { days, and pentosan polysulphate } 90 \text { days prior to evaluation. } \\
\text { During the evaluation the research team were unaware of which limb had been } \\
\text { operated on and the technique used. } \\
\text { Follow-up time between surgery and evaluation visit was between } 1.5 \text { and } 4.4 \text { years. }\end{array}$ \\
\hline Study design: & Retrospective case series \\
\hline $\begin{array}{l}\text { Outcome } \\
\text { studied: }\end{array}$ & 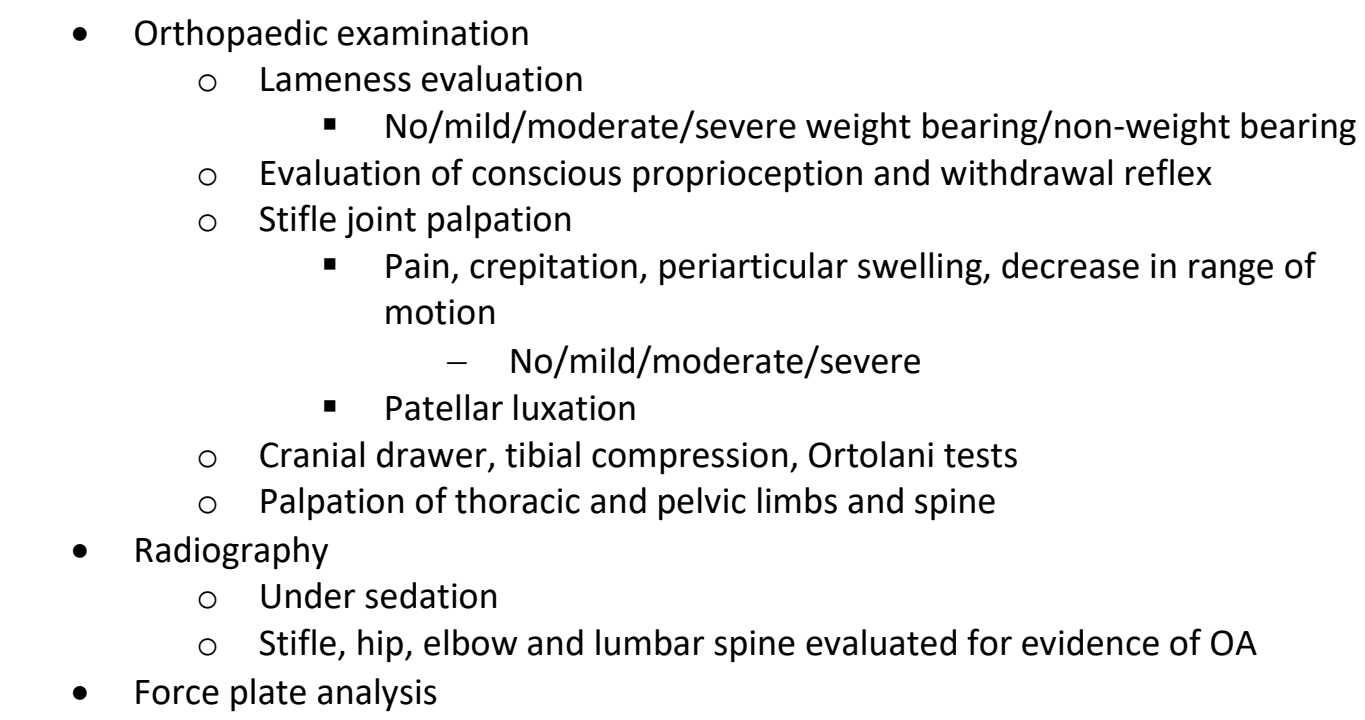 \\
\hline
\end{tabular}




\begin{tabular}{|c|c|c|}
\hline & $\begin{array}{r}0 \\
0 \\
0 \\
\\
\text { - Physio } \\
0 \\
0 \\
0 \\
\\
0 \\
0 \\
\\
0 \\
\text { - Gonior } \\
0\end{array}$ & $\begin{array}{l}\text { Data from five valid trials for each side were normalised for body mass } \\
\text { and averaged } \\
\text { Peak vertical forces and vertical impulses were evaluated in all limbs } \\
\text { Distribution percentages of peak vertical forces per limb were } \\
\text { calculated } \\
\text { A symmetry index was calculated for pelvic limb peak vertical force } \\
\text { and vertical impulse } \\
\text { - } \quad 0 \text { indicates perfect symmetry } \\
\text { A positive value indicates decreased weight bearing on the } \\
\text { - A negative value indicates decreased weight bearing on the } \\
\quad \text { contralateral limb } \\
\text { The control group values were used to determine the cut-off value for } \\
\text { differentiation between normal and lame dogs } \\
\text { herapeutic examination } \\
\text { Performed by a veterinary physiotherapist } \\
\text { Visual evaluation of lameness } \\
\text { Movement on stairs } \\
\text { Functional active range of motion and thrust from the ground } \\
\text { Manual evaluation of muscle atrophy of pelvic limbs } \\
\text { - Subjective assessment by palpating for symmetry } \\
\text { Manual evaluation and quantitative measurement of static weight } \\
\text { bearing } \\
\text { letry } \\
\text { Passive range of motion in stifle and tarsal joints }\end{array}$ \\
\hline $\begin{array}{r}\text { Main findings: } \\
\text { (relevant to PICO } \\
\text { question): }\end{array}$ & 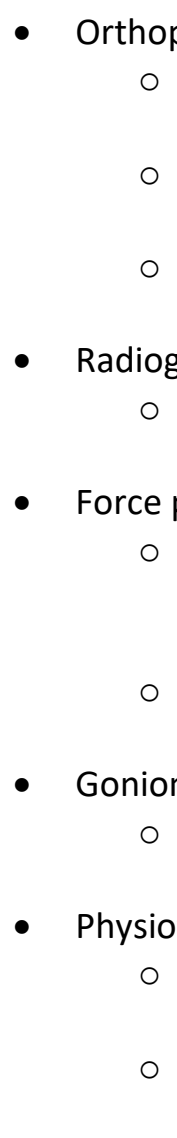 & $\begin{array}{l}\text { The severity of stifle joint crepitation was significantly lower in the } \\
\text { osteotomy group than in the LFS group. } \\
\text { The amount of periarticular swelling was significantly lower in the } \\
\text { osteotomy than in the LFS group. } \\
\text { No significant differences were found between surgical techniques in } \\
\text { pain response to stifle joint flexion/extension. } \\
\text { aphy } \\
\text { Comparison between osteotomy and LFS repair was not possible from } \\
\text { the results reported. } \\
\text { late analysis } \\
\text { When force plate results of different surgical technique groups were } \\
\text { evaluated, no significant differences were found between treatment } \\
\text { groups. } \\
\text { The low number of dogs treated with the LFS technique precluded } \\
\text { comparison of ground reaction forces to other techniques. } \\
\text { letry } \\
\text { No significant differences were found between surgical technique } \\
\text { groups. } \\
\text { herapeutic examination } \\
\text { No significant differences were found between surgical technique } \\
\text { groups. } \\
\text { The low number of dogs treated with LFS prevented comparison of } \\
\text { static weight bearing to other techniques. }\end{array}$ \\
\hline Limitations: & \multicolumn{2}{|c|}{$\begin{array}{l}\text { - Results were collected from six individual referral practices, practice was not } \\
\text { investigated as a confounding variable. }\end{array}$} \\
\hline
\end{tabular}




\begin{tabular}{|c|c|}
\hline & 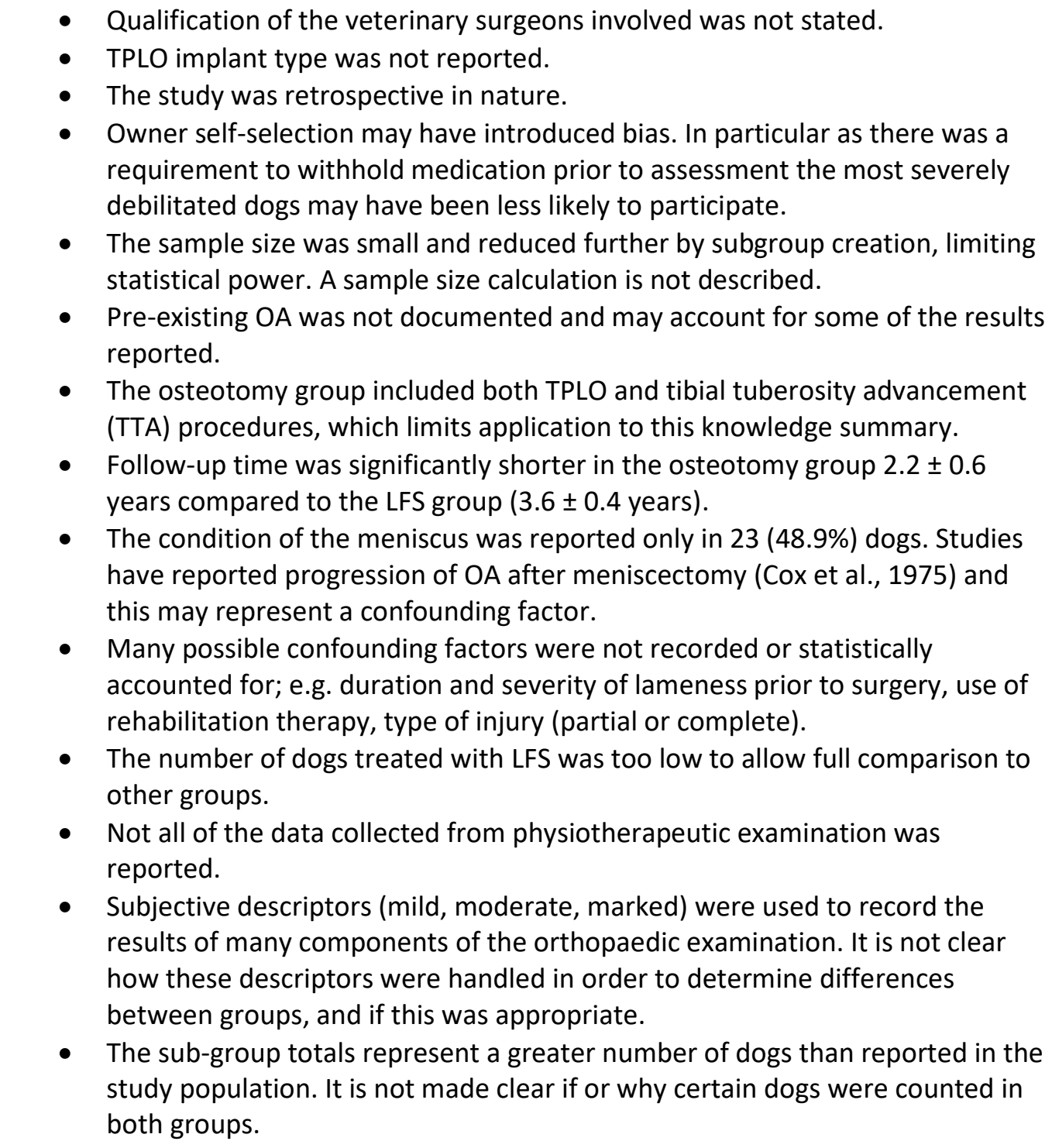 \\
\hline \multicolumn{2}{|l|}{ Molsa et al. (2013) } \\
\hline Population: & $\begin{array}{l}\text { Dogs of various breeds and crossbreeds, with naturally occurring cranial cruciate } \\
\text { disease (unilateral or bilateral), with or without meniscal injury, repaired surgically } \\
\text { using either an intracapsular, LFS or osteotomy technique (TPLO or TTA). } \\
\text { The mean weight of dogs was } 30.0 \pm 17.9 \mathrm{~kg} \text {. } \\
\text { The mean age of dogs was } 5.9 \pm 3.3 \text { years. } \\
\text { Dogs were excluded if they had concomitant stifle joint disease at the time of the } \\
\text { initial surgery, or if more than one technique was performed on the same limb. }\end{array}$ \\
\hline Sample size: & 253 dogs \\
\hline $\begin{array}{r}\text { Intervention } \\
\text { details: }\end{array}$ & $\begin{array}{l}\text { Medical records of dogs presenting to the Veterinary Teaching Hospital of the } \\
\text { University of Helsinki or one of five private orthopaedic referral clinics in Finland } \\
\text { between January } 2004 \text { and December } 2006 \text { were reviewed. } \\
\text { A questionnaire designed to evaluate long-term outcome and prevalence of chronic } \\
\text { pain after surgical repair by means of intracapsular, extracapsular, or osteotomy } \\
\text { techniques was sent to the owners of dogs that fulfilled the inclusion criteria. } \\
\text { If the dog underwent surgery bilaterally, the owner was asked to answer based on the }\end{array}$ \\
\hline
\end{tabular}




\begin{tabular}{|c|c|}
\hline & $\begin{array}{l}\text { surgery performed between } 2004 \text { and } 2006 \text {. If both stifle joints underwent surgery } \\
\text { during this period, the owner was asked to answer based on the later surgery. } \\
87 \text { dogs received a LFS, } 63 \text { dogs received an osteotomy procedure, of which } 34 \text { were } \\
\text { TPLOs, } 88 \text { dogs received an intracapsular technique and } 15 \text { dogs received more than } \\
\text { one surgeries on the limb with multiple techniques } \\
\text { The follow-up time (interval between surgery and the questionnaire) was between } 1.3 \\
\text { and } 4.5 \text { years. }\end{array}$ \\
\hline Study design: & Retrospective case series \\
\hline $\begin{array}{l}\text { Outcomes } \\
\text { studied: }\end{array}$ & $\begin{array}{l}\text { - Owner questionnaire } \\
\circ \text { Signalment information } \\
\circ \text { Information regarding the injury and surgery } \\
\circ \text { Duration of postoperative lameness } \\
\circ \text { Need for long-term administration of nonsteroidal anti-inflammatory } \\
\text { drugs (NSAIDs) and frequency of use } \\
\circ \text { Use of postoperative physiotherapy } \\
\circ \text { Opinion of surgical outcome } \\
\text { - Excellent, good, fair or poor } \\
\text { Helsinki Chronic Pain Index (HCPI) (Hielm-Björkman et al., 2009) } \\
\quad \text { Previously validated for healthy dogs and those with hip and } \\
\quad \text { - } 11 \text { questions regarding mood, behaviour and locomotion } \\
\text { - Always, very often, often, sometimes, hardly ever. } \\
\text { Willingness to bear weight equally. }\end{array}$ \\
\hline $\begin{array}{r}\text { Main findings: } \\
\text { (relevant to PICO } \\
\text { question): }\end{array}$ & $\begin{array}{l}\text { - No significant difference was found between surgical techniques in frequency } \\
\text { of lameness or willingness to bear weight on the treated limb at follow-up. } \\
\text { - The HCPI in the osteotomy group was significantly lower than dogs that were } \\
\text { treated with an extracapsular technique, however this was not the case after } \\
\text { adjusting for the difference in age between groups. } \\
\text { - The authors concluded that 'Owner assessments revealed no significant } \\
\text { differences in long-term outcomes between surgical techniques'. }\end{array}$ \\
\hline Limitations: & $\begin{array}{l}\text { - The study was retrospective in nature and required owner recollection of past } \\
\text { events, which may not have been accurately reported. } \\
\text { - } \quad \text { Details of meniscus assessment and if a tear was present and treated was } \\
\text { reported only in } 126 / 253(49.8 \%) \text { cases, so could not be controlled as a } \\
\text { confounding factor. } \\
\text { - A sample size calculation is not described. } \\
\text { - Qualification of the veterinary surgeons involved, was not stated. } \\
\text { - Other concomitant orthopaedic or neurological disease was not a criteria for } \\
\text { - } \quad \text { Activity levels postsurgery, rehabilitation and medication use was not } \\
\text { - } \text { standardised. } \\
\text { - Resu implant type was not reported. } \\
\text { investigated as a confounding variable. }\end{array}$ \\
\hline
\end{tabular}




\begin{tabular}{|l|l|}
\hline - There were likely many other confounding factors due to the heterogeneous \\
population involved. \\
- The population of dogs receiving LFS was significantly older than the \\
population receiving an osteotomy procedure. \\
- There was a significant difference in body weight between groups. It is not \\
reported which groups were heavier. \\
- Owner assessment of lameness may not be accurate. \\
- The follow-up period was significantly shorter in the osteotomy group ( $2.2 \pm$ \\
o.7 years compared to $2.9 \pm 0.8$ years for LFS group). This is likely to have \\
affected both function and accuracy of owner recollection. \\
- The osteotomy group included both TPLO and TTA procedures, which limits \\
application to this knowledge summary. \\
The number of dogs receiving a TPLO (34) reduced the study's statistical \\
power.
\end{tabular}

\begin{tabular}{|c|l|}
\hline Nelson et al. (2013) \\
\hline Population: & $\begin{array}{l}\text { Treatment group: Adult dogs of various breeds and crossbreeds, over } 15 \mathrm{~kg} \\
\text { bodyweight, with naturally occurring unilateral CCL rupture (partial or complete), } \\
\text { treated surgically with either placement of a LFS or TPLO. Animals were excluded if } \\
\text { there were any other abnormalities (including orthopaedic abnormalities) detected } \\
\text { on clinical examination, or if any radiographic abnormalities were present on a } \\
\text { ventrodorsal projection extended hip radiograph. Dogs were required to have an } \\
\text { adequate stride length to obtain accurate ground reaction force profile. }\end{array}$ \\
& $\begin{array}{l}\text { Control: Adult dogs over } 15 \mathrm{~kg} \text {, with no abnormalities on physical and orthopaedic } \\
\text { examination and no evidence of skeletal disease on a ventrodorsal projection } \\
\text { extended hip radiograph. Animals were excluded from this group if they had any } \\
\text { history of orthopaedic or neurological disease; or current history of persistent injury } \\
\text { or systemic disease. }\end{array}$ \\
\hline Sample size: & $\begin{array}{l}\text { Treatment group: } 38 \text { dogs } \\
\text { Control group: } 79 \text { dogs }\end{array}$ \\
\hline
\end{tabular}




\begin{tabular}{|c|c|}
\hline $\begin{array}{r}\text { Intervention } \\
\text { details: }\end{array}$ & $\begin{array}{l}\text { Dogs admitted to Cornell University Veterinary Teaching Hospital, for surgical } \\
\text { treatment of CCL rupture between July } 2007 \text { and August } 2010 \text { were evaluated for } \\
\text { inclusion. Dogs were allocated into treatment group (LFS or TPLO) based on owner } \\
\text { preference. Control dogs were recruited from the community. } \\
\text { Anaesthesia protocol was not standardised. All dogs received } 22 \mathrm{mg} / \mathrm{kg} \text { cefazolin } \\
\text { perioperatively every } 90 \text { minutes until conclusion of anaesthesia. } \\
\text { In order to evaluate the CCL and medial meniscus craniomedial arthrotomy, } \\
\text { craniomedial mini-arthrotomy, or arthroscopy was performed at the surgeon's } \\
\text { discretion. If a meniscal tear was present a partial meniscectomy was performed. } \\
\text { Joint capsule or arthroscopy incisions were closed routinely. } \\
\text { TPLO (15 procedures) was performed as described by Slocum \& Slocum (1993), } \\
\text { without the use of a jig. A locking plate was used to secure the osteotomy. LFS ( } 23 \\
\text { procedures) was performed with a lateral fabellotibial or lateral and medial } \\
\text { fabellotibial suture. A bone tunnel was drilled in the tibial tuberosity. Two sutures of } \\
80 \text { Ib. or } 100 \text { lb. monofilament nylon were placed around the lateral or lateral and } \\
\text { medial femorofabellar ligament and through the bone tunnel. Sutures were tightened } \\
\text { until cranial drawer was eliminated and secured with either a self-locking knot or } \\
\text { crimps. } \\
\text { Postoperative analgesia was not standardised. A modified Robert Jones bandage was } \\
\text { applied after surgery and changed daily until cessation of discharge. The incision was } \\
\text { cold-packed daily until discharge. Owners were given standardised instructions for } \\
\text { postoperative care; these included medications (tramadol, NSAID and a transdermal } \\
\text { fentanyl patch) and a basic rehabilitation programme ( } 8 \text { weeks restricted exercise, } \\
\text { passive and active range of motion and sit to stand exercises). } \\
\text { Follow-up was performed at between } 1 \text { and } 49 \text { days ( } 2 \text { week follow-up), between } 50 \\
\text { and } 149 \text { days ( } 8 \text { week follow-up), between } 150 \text { and } 299 \text { days ( } 6 \text { month follow-up) and } \\
300 \text { days+ (one year follow-up) postsurgery. }\end{array}$ \\
\hline Study design: & Non-randomised, prospective, observational clinical study \\
\hline Outcome studied: & $\begin{array}{l}\text { - Force plate gait analysis } \\
\circ \text { Performed in control dogs during a single session } \\
\circ \text { Performed in treated dogs preoperatively and } 1 \text { day, } 2 \text { days, } 2 \text { weeks, } \\
8 \text { weeks, } 6 \text { months, and } 1 \text { year postoperatively } \\
\circ \begin{array}{r}\text { Walk }=\text { velocity } 0.75-1.25 \mathrm{~m} / \mathrm{s} \\
\text { - Assessed at all time points } \\
\circ \quad \text { Trot }=\text { velocity } 1.75-2.25 \mathrm{~m} / \mathrm{s} \\
\text { - Assessed preoperatively and from } 8 \text { weeks postoperatively } \\
\text { A symmetry index was calculated for all ground reaction forces } \\
\text { - Used to evaluate weight-bearing between two limbs as } \\
\text { symmetrical }(1.0) \text { or asymmetrical }(<\text { or }>1.0)\end{array}\end{array}$ \\
\hline $\begin{array}{r}\text { Main findings: } \\
\text { (relevant to PICO } \\
\text { question): }\end{array}$ & $\begin{array}{l}\text { - Symmetry indices compared to control group } \\
\circ \text { All symmetry indices (peak vertical force and vertical impulse at both } \\
\text { walk and trot) were significantly lower (less symmetrical) in the LFS } \\
\text { group than in the control group at all postoperative time points. } \\
\circ \text { The symmetry indices for the TPLO group at the walk (peak vertical }\end{array}$ \\
\hline
\end{tabular}




\begin{tabular}{|c|c|}
\hline & $\begin{array}{l}\text { force and vertical impulse) were not significantly different to the } \\
\text { control group from day } 150 \text { postoperatively } \\
\circ \text { The symmetry index for the TPLO group peak vertical force at the trot } \\
\text { was not significantly different to the control group from day } 150 \\
\text { postoperatively } \\
\text { The symmetry index for the TPLO group vertical impulse at the trot } \\
\text { was not significantly different to the control group from day } 300 \\
\text { postoperatively } \\
\text { - Symmetry when comparing treatment groups } \\
\text { At the walk the TPLO group was significantly more symmetrical than } \\
\text { the LFS group for both peak vertical force and vertical impulse from } \\
\text { day } 50-149 \text { postoperatively and after day } 300 \text { postoperatively } \\
\circ \quad \text { For peak vertical force at the trot the TPLO group was significantly } \\
\text { more symmetrical than the LFS group at all postoperative time points } \\
\circ \quad \text { For vertical impulse at the trot the TPLO group was significantly more } \\
\text { symmetrical than the LFS group from day } 50 \text { postoperatively } \\
\text { Contact time } \\
\text { Contact time at the walk and trot showed no difference between } \\
\text { TPLO and LFS groups at any time point and both groups were not } \\
\text { statistically different to the control group from day } 50 \\
\text { postoperatively }\end{array}$ \\
\hline Limitations: & $\begin{array}{l}\text { - This was a non-randomised, observational study, increasing the likelihood of } \\
\text { unidentified confounding factors affecting results } \\
\text { - This is a single centre study which may limit application to other centres } \\
\text { - Qualification of the veterinary surgeons involved was not stated. } \\
\text { - Treatment group was determined by owner preference. This is likely to } \\
\text { introduce confounding factors } \\
\text { - Sample size was small - only } 18 \text { dogs completed the gait analysis to } 12 \\
\text { months follow-up, this limits statistical power } \\
\text { - NSAID use postoperatively was variable } \\
\text { - The TPLO group were significantly younger than the LFS group } \\
\text { - There was variability in the LFS technique used } \\
\text { - Use of specialised diet, nutraceuticals or more intensive rehabilitation was } \\
\text { not recorded or accounted for statistically }\end{array}$ \\
\hline \multicolumn{2}{|c|}{ Gordon-Evans et al. (2013), addendum Gordon-Evans (2016) } \\
\hline Population: & $\begin{array}{l}\text { Adult dogs (age range 2-12 years) of various breeds, with naturally occurring, } \\
\text { unilateral CCL rupture (partial or complete), treated surgically with either placement } \\
\text { of a LFS or TPLO. Animals were excluded if there was evidence of medical or } \\
\text { neurological disease, or if they showed fractious or aggressive behaviour. Animals } \\
\text { were not excluded due to previous history of orthopaedic disease provided they had } \\
\text { no associated signs of pain or lameness at initial evaluation and any surgery had been } \\
\text { performed more than } 6 \text { months prior to enrollment. }\end{array}$ \\
\hline Sample size: & 80 dogs \\
\hline Intervention & Dogs were assigned via block randomisation to receive either LFS (40) or TPLO (40); \\
\hline
\end{tabular}




\begin{tabular}{|c|c|}
\hline details: & $\begin{array}{l}\text { controlling for bodyweight at a BCS of } 5 \text { (small or medium breed, }<18 \mathrm{~kg} \text {; large breed, } \\
\text { 18-36.4 kg; or giant breed, > } 36.4 \mathrm{~kg} \text { ). } \\
\text { Premedications, anaesthetics and analgesics were not standardised. Arthroscopic } \\
\text { exploration of the stifle joint was performed. The CCL was debrided and the menisci } \\
\text { were evaluated. Meniscal tears were debrided, or a medial caudal pole meniscectomy } \\
\text { performed if damage was severe. If this was not possible arthroscopically a medial } \\
\text { arthrotomy was performed. For both procedures, a skin incision was created on the } \\
\text { medial aspect of the stifle joint region. } \\
\text { All procedures were performed by or under the supervision of a board certified } \\
\text { surgeon. TPLO was performed as described by Slocum \& Slocum (1993). } \\
\text { LFS procedure - a lateral retinacular incision was created and two strands of } 60-, 80-\text {, } \\
\text { or } 100-\text { Ib nylon suture were passed around the lateral fabella, under the patellar } \\
\text { ligament, and through a hole in the proximal tibial tuberosity in a figure of eight } \\
\text { pattern. The suture was tightened until } 90^{\circ} \text { of flexion could be maintained without } \\
\text { eliciting a cranial drawer before crimping. } \\
\text { Skin incisions were closed with staples or sutures. } \\
\text { Patients received } 10 \text { days of tramadol and various NSAIDs postoperatively. Analgesia } \\
\text { after } 10 \text { days was not standardised. Discharge instructions were similar and included } \\
\text { rehabilitation therapy exercises performed three times daily. Owners were unaware } \\
\text { of the procedure performed unless complications required disclosure. }\end{array}$ \\
\hline Study design: & Randomised, blinded, controlled clinical trial. \\
\hline Outcome studied: & $\begin{array}{l}\text { - Preoperatively, postoperatively at } 6 \text { weeks, } 12 \text { weeks, } 6 \text { months and } 12 \\
\text { months; } \\
\circ \text { Force plate gait analysis } \\
\text { - Wan values for } 5 \text { trials reported as a percentage of weight }(1-1.3 \mathrm{~m} / \mathrm{s}) \\
\text { - Trot }(1.5-1.8 \mathrm{~m} / \mathrm{s}) \\
\circ \text { Canine brief pain inventory (validated owner questionnaire) } \\
\circ \text { Thigh circumference } \\
\text { - Stifle joint goniometry } \\
6 \text { and } 12 \text { months postoperatively } \\
\circ \text { Owners asked to rate surgical outcome } \\
\text { - } 1-10\end{array}$ \\
\hline $\begin{array}{r}\text { Main findings: } \\
\text { (relevant to PICO } \\
\text { question): }\end{array}$ & $\begin{array}{l}\text { - Surgical time was significantly longer for the TPLO group than the LFS group } \\
\text { - Complication rates were similar between groups } \\
\text { - Rate of late meniscal injury was not significantly different between groups } \\
\text { - Force platform analysis } \\
\text { O At } 6 \text { months postoperatively peak vertical force values at trot were } \\
\text { significantly higher in the TPLO group. Peak vertical forces at walk } \\
\text { were not significantly different between groups } \\
\text { At } 12 \text { months postoperatively peak vertical force and vertical impulse } \\
\text { values were significantly higher for dogs in the TPLO group at both } \\
\text { walk and trot } \\
\text { - Canine Brief Pain Inventory owner survey }\end{array}$ \\
\hline
\end{tabular}




\begin{tabular}{|c|c|}
\hline & $\begin{array}{l}\text { - No significant difference between treatment groups } \\
\text { - Thigh circumference } \\
\text { - No significant difference between treatment groups } \\
\text { Stifle joint goniometry } \\
\circ \text { No significant difference between treatment groups } \\
\text { - Owner satisfaction rating } \\
\circ \text { Rating at } 6 \text { months was not significantly different between groups } \\
\circ \quad \text { Rating at } 12 \text { months was significantly higher (improved satisfaction) } \\
\text { in the TPLO group } \\
\text { - An addendum calculating the number of dogs that would need to be treated } \\
\text { with a TPLO procedure in order to see an overall improvement in success } \\
\text { (NNT) was published in } 2016 \\
\circ \quad \text { NNT for overall improvement in owner satisfaction was seven } \\
\circ \quad \text { NNT for improvement in limb function as measured by peak vertical } \\
\text { force (defined as number of dogs achieving a peak vertical force } \\
\text { greater than } 35 \% \text { of weight at walk and } 58 \% \text { at trot at } 12 \text { months } \\
\text { postoperatively) was six }\end{array}$ \\
\hline Limitations: & $\begin{array}{l}\text { - This is a single centre study which may limit application to other centres } \\
\text { - The owner survey used to assess satisfaction is a subjective, non-validated } \\
\text { tool } \\
\text { - TPLO implant type was not reported } \\
\text { - Analgesia protocols from day } 10 \text { postoperatively were not standardised } \\
\text { (though use was assessed statistically and not found to be significantly } \\
\text { different between groups) } \\
\text { - Closure method was not standardised and may have been a confounding } \\
\text { factor }\end{array}$ \\
\hline
\end{tabular}

Frey et al. (2010)

Population: Dogs of various breeds and crossbreeds, with naturally occurring unilateral or bilateral cranial cruciate ligament rupture (partial or complete), with or without meniscal injury, stabilised surgically with either LFS or a TPLO.

Dogs were excluded if concurrent orthopaedic surgical procedures (including stabilisation of the contralateral stifle joint) were performed during the same anaesthetic.

Age and weight range were not reported.

Sample size: 808 dogs, 902 procedures

Intervention Medical records of all dogs that underwent a LFS stabilisation or TPLO as treatment

details: for cranial cruciate rupture, at Garden State Veterinary Specialists, between January 2005 and December 2006 were reviewed. Data regarding development of postoperative infection-inflammation were obtained. Potential risk factors were identified and recorded. Dogs that had contralateral CCL ruptures repaired during separate anaesthetic were included as two separate interventions.

Anaesthetic protocol and analgesics were not standardised. All dogs received 22 $\mathrm{mg} / \mathrm{kg}$ cefazolin prophylactically at induction and every 120 minutes thereafter until conclusion of anaesthesia. Antimicrobial administration after surgery was at the surgeon's discretion. The hind-limb was clipped and aseptically prepared in a routine 


\begin{tabular}{|c|c|}
\hline & $\begin{array}{l}\text { manner. } \\
\text { LFS ( } 496 \text { procedures) was performed through a lateral parapatellar incision. Lateral } \\
\text { arthrotomy was performed to allow meniscal inspection and debridement of CCL } \\
\text { remnants. The stifle joint was stabilised with one or two circumfabellotibial } \\
\text { monofilament nylon sutures secured with hand ties or metal crimps. The biceps fascia } \\
\text { was imbricated, subcutaneous tissue and skin were closed in a routine manner. TPLO } \\
\text { (406 procedures) was performed as described by Slocum \& Slocum (1993) with minor } \\
\text { variations in technique in accordance with surgeon preference. Cortical screws were } \\
\text { used. A medial arthrotomy was performed to allow meniscal inspection and } \\
\text { debridement of CCL remnants. } \\
\text { Rate of surgical site infection-inflammation was recorded at suture removal and at } \\
\text { follow-up within } 6 \text { months. }\end{array}$ \\
\hline Study design: & Retrospective case series \\
\hline Outcome studied: & $\begin{array}{l}\text { Infection-inflammation rate: } \\
\text { - At suture removal (within } 21 \text { days postoperatively) wounds were classified as } \\
\text { infected-inflamed when purulent discharge, abscessation or fistulation were } \\
\text { present or where three or more of the following were evident at the wound } \\
\text { simultaneously: } \\
\circ \text { Erythema } \\
\circ \text { Swelling } \\
\circ \text { Signs of pain } \\
\circ \text { Heat } \\
\circ \text { Serous discharge } \\
\circ \text { Dehiscence } \\
\text { At recheck (within } 6 \text { months postoperatively) wounds were classified using } \\
\text { the classification described above with the addition of joint effusion, } \\
\text { moderate-severe lameness and pain at palpation of the soft tissues overlying } \\
\text { the implant. }\end{array}$ \\
\hline $\begin{array}{r}\text { Main findings: } \\
\text { (relevant to PICO } \\
\text { question): }\end{array}$ & $\begin{array}{l}\text { - Infection-inflammation developed after } 55 / 902(6.1 \%) \text { of surgeries } \\
\circ \quad \text { The infection-inflammation rate for the LFS group }(21 / 496,4.2 \%) \text { was } \\
\text { significantly lower than that of the TPLO group }(34 / 406,8.4 \%) \\
\text { The odds ratio of TPLO to LFS surgery for the development of } \\
\text { infection-inflammation was } 2.068 \\
\text { - There was a significant increase in the rate of infection-inflammation when } \\
\text { comparing closure with skin staples to closure with sutures } \\
\circ \text { The odds of developing postoperative infection-inflammation were } \\
1.9 \text { times as high in these patients } \\
\circ \quad \text { TPLO surgeries were } 6.7 \text { times more likely to be closed with stainless- } \\
\text { steel staples } \\
\text { - There was no significant difference in the rate of inflammation-infection } \\
\text { when comparing closure with staples between groups, or comparing closure } \\
\text { with sutures between groups } \\
\text { Odds ratio calculations showed that a TPLO increased the risk of } \\
\text { postoperative infection-inflammation by a factor of } 1.2 \text { when staples } \\
\text { were used and a factor of } 1.8 \text { when staples were not used } \\
\text { - This was not significantly different } \\
\text { Patients receiving oral antimicrobials at discharge had a } 5.1 \% \text { rate of } \\
\text { infection-inflammation (39/771), patients not receiving oral antimicrobials at }\end{array}$ \\
\hline
\end{tabular}




\begin{tabular}{|c|c|}
\hline & 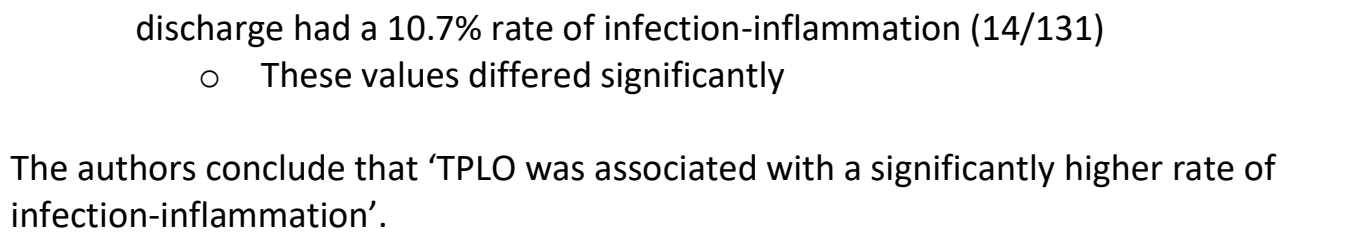 \\
\hline Limitations: & $\begin{array}{l}\text { - This is a single centre study which may limit application to other centres. } \\
\text { - Tualification of the veterinary surgeons involved was not stated. } \\
\text { wounds. Need for treatment, increased cost and morbidity would be } \\
\text { expected to be very different depending on the presence of infection, and } \\
\text { thus the clinical relevance of these findings is not clear. } \\
\text { - Wounds were retrospectively categorised as infected-inflamed based on } \\
\text { previously recorded details entered by a number of observers and data would } \\
\text { be expected to be subject to inter-observer bias in addition to possible under- } \\
\text { reporting. } \\
\text { - The rate of wounds which required additional treatment or monitoring is not } \\
\text { reported. } \\
\text { Mean duration of anaesthesia and mean body weight differed significantly } \\
\text { with respect to the procedure (the TPLO group were heavier and had longer } \\
\text { anaesthetics). The data was stratified and groups compared at } 10 \text { kg/10 } \\
\text { minute intervals in an attempt to account for this. Odds ratios calculated for } \\
\text { the strata with greatest overlap did suggest that duration of anaesthesia and } \\
\text { mean body weight were not confounding variables, however sample sizes } \\
\text { would be much reduced in these groups. } \\
\text { Presence of concurrent infection was not found to significantly affect the rate } \\
\text { of postoperative infection-inflammation, however screening for the presence } \\
\text { of concurrent infection did not appear to be standardised and could } \\
\text { represent a confounding factor. } \\
\text { - A non-locking implant was used for TPLO procedures - newer locking plates } \\
\text { have been associated with a lower risk of infection (Solane et al., 2015). } \\
\text { - Follow-up time was categorised as within } 21 \text { days and within } 6 \text { months. } \\
\text { Grading wounds at more specific time intervals may have produced different } \\
\text { results. Revisit times may represent a confounding factor. } \\
\text { may represent confounding factors. } \\
\text { Age and weight range were not reported. }\end{array}$ \\
\hline \multicolumn{2}{|l|}{ Au et al. (2010) } \\
\hline Population: & $\begin{array}{l}\text { Dogs of various breeds and crossbreeds, between } 10 \text { and } 60 \mathrm{~kg} \text { bodyweight, with } \\
\text { naturally occurring unilateral or bilateral } C C L \text { disease, with or without medial } \\
\text { meniscal injury, treated surgically with either placement of a LFS or TPLO. Age range } \\
2-11 \text { years. } \\
\text { Animals were excluded if they had evidence of other orthopaedic or neurological } \\
\text { disease as determined by clinical examination at admission. }\end{array}$ \\
\hline Sample size: & 65 dogs \\
\hline $\begin{array}{r}\text { Intervention } \\
\text { details: }\end{array}$ & $\begin{array}{l}\text { Patients were allocated into treatment groups on the basis of owner preference. } \\
\text { Patients developing } C C L \text { disease in the opposite limb during the study were not }\end{array}$ \\
\hline
\end{tabular}




\begin{tabular}{|c|c|}
\hline & $\begin{array}{l}\text { excluded. } \\
\text { NSAIDs were withheld for at least } 1 \text { week before surgery. Patients received a } \\
\text { standard premedication and non-standardised induction protocol. Cefazolin ( } 22 \\
\text { mg/kg I.V) was administered perioperatively. } \\
\text { All procedures were performed by residents under the supervision of board certified } \\
\text { veterinary surgeons. LFS procedure ( } 35 \text { dogs): craniolateral arthrotomy with } \\
\text { inspection of the menisci and debridement of CCL remnants. Lateral sutures of } 80 \mathrm{lb} \\
\text { monofilament nylon were placed around the lateral fabella and through a hole in the } \\
\text { tibial crest. The sutures were tensioned to eliminate cranial drawer motion before } \\
\text { fastening with a single Securos crimp clamp. A single suture was inserted in dogs }<25 \\
\text { kg and two sutures in dogs }>25 \text { kg. TPLO procedure ( } 30 \text { dogs): craniomedial } \\
\text { arthrotomy with inspection of menisci, prior to TPLO performed as described by } \\
\text { Slocum \& Slocum (1993). } \\
\text { In both procedures medial meniscal injury was treated by caudal pole meniscectomy. } \\
\text { An abaxial medial meniscal release was performed at the surgeon's discretion. } \\
\text { Postoperative analgesia was provided by hydromorphone for } 24 \text { hours } \\
\text { postoperatively followed by deracoxib or carprofen for } 7 \text { days postoperatively. } \\
\text { All dogs had an identical physical rehabilitation regime performed by the same } \\
\text { handler. Physical rehabilitation was performed twice daily for } 5 \text { days during weeks } 3 \text {, } \\
5 \text {, and } 7 \text { postoperatively. NSAIDs were administered during these weeks but } \\
\text { discontinued in between. Sessions consisted of: } \\
\bullet \quad 5 \text { minutes of passive range of motion exercises } \\
\text { - } 10 \text { minutes of land treadmill walking } \\
\text { • } 10 \text { minutes of underwater treadmill walking } \\
\text { During weeks } 4,6,8,9,10,11 \text { and } 12 \text { home exercises involving passive range of } \\
\text { motion were prescribed. } \\
\text { Follow-up was between } 6 \text { and } 24 \text { months. }\end{array}$ \\
\hline Study design: & Non-randomised, prospective observational clinical study \\
\hline Outcome studied: & $\begin{array}{l}\text { - Gait analysis } \\
\circ \text { Peak vertical force measurements for each pelvic limb } \\
\circ \text { Assessed pre-operatively, 3, } 5 \text { and } 7 \text { weeks, } 6 \text { and } 24 \text { months } \\
\text { postoperatively. } \\
\circ \text { Data was collected at a walk (1.5-1.8 m/s) } \\
\text { - Goniometry } \\
\circ \text { Both affected and contralateral stifle joints. } \\
\circ \text { Assessed pre-operatively, 3, } 5 \text { and } 7 \text { weeks, } 6 \text { and } 24 \text { months } \\
\text { postoperatively } \\
\text { - Thigh circumference } \\
\circ \text { At the level of the proximal quarter of the femur on both pelvic limbs } \\
\circ \text { Assessed pre-operatively, 3, } 5 \text { and } 7 \text { weeks, } 6 \text { and } 24 \text { months } \\
\text { postoperatively } \\
\text { Radiography } \\
\circ \text { Preoperatively and at } 2 \text { year follow-up } \\
\circ \text { Paired caudomedial and mediolateral stifle joint radiographs }\end{array}$ \\
\hline
\end{tabular}




\begin{tabular}{|c|c|}
\hline & $\begin{array}{l}\quad \text { Assessed by single board-certified radiologist } \\
\circ \text { Scored for signs of OA with a 21-factor scale based on a modification } \\
\text { of a system by Vasseur and Berry (1991). }\end{array}$ \\
\hline $\begin{array}{l}\text { Main findings: } \\
\text { (relevant to PICO } \\
\text { question): }\end{array}$ & $\begin{array}{l}\text { - Gait analysis } \\
\circ \quad \text { There was no significant difference in peak vertical force (PVF) } \\
\text { between groups at any time point } \\
\text { - Goniometry } \\
\circ \quad \text { There was no significant difference in stifle joint range of motion } \\
\text { between groups at any time point } \\
\text { - Thigh circumference } \\
\circ \quad \text { There was no significant difference between groups } \\
\text { - Radiography } \\
\circ \quad \text { There was no significant difference in OA scores between groups } \\
\text { - Complication rate } \\
\circ \quad \text { There was no significant difference in complication rates between } \\
\text { groups } \\
\text { The authors conclude that 'This study does not support the superiority of either } \\
\text { surgical technique.' }\end{array}$ \\
\hline Limitations: & $\begin{array}{l}\text { - This is a single centre study which may limit application to other centres. } \\
\text { - Treatment group was determined by owner preference. This is likely to } \\
\text { introduce confounding factors. } \\
\text { - This was a non-randomised, observational study, increasing the likelihood of } \\
\text { - The mean age of the LFS group was significantly older than the TPLO group. } \\
\text { - The mean weight of the LFS group was significantly less than the TPLO group. } \\
\text { - Patients underwent an intense rehabilitation protocol, similar aftercare may } \\
\text { not be realistic for a typical population. This may have reduced the difference } \\
\text { in outcome between groups as a later study suggested without a formal } \\
\text { rehabilitation programme patients receiving TPLO had a faster return to } \\
\text { function. } \\
\text { - } \quad \text { Son-locking implants were used in TPLO procedures. } \\
\text { - Gait analysis was performed at walking velocity only. It has previously been } \\
\text { demonstrated that analysis of trotting velocity is a superior indicator of } \\
\text { lameness when evaluating low-grade pelvic limb lameness in dogs (Voss et } \\
\text { al., 2007). } \\
\text { - A sample size calculation is not described and thus it is not clear if the study's } \\
\text { power could reasonably be expected to detect a significant difference } \\
\text { between groups. For example the authors report a greater improvement was } \\
\text { seen in PVF in the TPLO group compared with the LFS group between } 6 \text { and } \\
24 \text { months postoperatively, however this difference was not statistically } \\
\text { - Ignificant. } \\
\text { - It is not reported if type of CCL rupture (partial or complete) was a criteria for } \\
\text { inclusion, and statistical analysis does not appear to account for this as a } \\
\text { confounding factor. } \\
\text { intensive rehabilitation was not recorded or accounted for statistically. } \\
\text { accounted for statistically. }\end{array}$ \\
\hline
\end{tabular}




\begin{tabular}{|c|c|}
\hline & $\begin{array}{l}\text { - Labrador retrievers were over represented in the TPLO group. } \\
\text { - Weight range was } 10-60 \mathrm{~kg} \text { therefore some animals would be included that } \\
\text { would not meet the criteria specified by this PICO. }\end{array}$ \\
\hline \multicolumn{2}{|c|}{ Conzemius et al. (2005) } \\
\hline Population: & $\begin{array}{l}\text { Treatment group: Labrador Retrievers with naturally occurring, unilateral cranial } \\
\text { cruciate rupture (partial or complete) and concomitant medial meniscal injury; } \\
\text { treated surgically using either an intracapsular technique, LFS or TPLO with } \\
\text { meniscectomy (partial or complete). } \\
\text { Dogs were excluded if intraoperative complications were reported during the surgery } \\
\text { or if bilateral disease was present. Age and weight range were not reported. } \\
\text { Control group: staff or student owned Labrador Retrievers, clinically normal as } \\
\text { determined by history taking, physical examination and stifle joint radiography. }\end{array}$ \\
\hline Sample size: & $\begin{array}{l}\text { Treatment group: } 131 \text { dogs } \\
\text { Control group: } 17 \text { dogs }\end{array}$ \\
\hline $\begin{array}{r}\text { Intervention } \\
\text { details: }\end{array}$ & $\begin{array}{l}\text { From June } 1998 \text { to September 2002, all Labrador Retrievers that were admitted to } \\
\text { the Veterinary Teaching Hospital at lowa State University for CCL were evaluated for } \\
\text { inclusion in the study. Dogs were allocated into treatment groups on the basis of } \\
\text { owner and surgeon preference. } \\
\text { LFS ( } 47 \text { procedures) was performed with sutures of various sizes. TPLO ( } 64 \\
\text { procedures) was performed as described in the licensing course. } 20 \text { dogs received an } \\
\text { intracapsular repair. } \\
\text { Force platform gait analysis was performed on the treatment group and control dogs. } \\
\text { Anti-inflammatory medication was stopped for } 7 \text { days prior to gait analysis. Clinically } \\
\text { important improvement was defined as limb function vertical forces at } 6 \text { months } \\
\text { closer to mean limb function of clinically normal dogs than mean limb function of } \\
\text { treatment group dogs presurgery. } \\
\text { Follow-up was performed at } 2 \text { and } 6 \text { months postsurgery. }\end{array}$ \\
\hline Study design: & Non-randomised, prospective, observational clinical study \\
\hline Outcome studied: & $\begin{array}{l}\text { - Force platform gait analysis } \\
\text { Evaluated prior to surgery and repeated } 2 \text { and } 6 \text { months } \\
\text { postoperatively } \\
\circ \text { At walking velocity (velocity } 1.0-1.3 \mathrm{~m} / \mathrm{s} \text { acceleration, } \pm 0.5 \mathrm{~m} / \mathrm{s}^{2} \text { ) } \\
\text { - } \text { Mean falling slope } \\
\text { - } \text { Peak vertical force } \\
\text { A logistic regression impulse } \\
\text { probability that an individual dog could be differentiated from the } \\
\text { control group } 6 \text { months after surgery }\end{array}$ \\
\hline $\begin{array}{r}\text { Main findings: } \\
\text { (relevant to PICO } \\
\text { question): }\end{array}$ & $\begin{array}{l}\text { When mean function was compared between TPLO and LFS groups no significant } \\
\text { difference was found over the duration of the study, or at any single time point. } \\
\text { There was no significant difference between TPLO and LFS groups in the probability of } \\
\text { a return to normal function. }\end{array}$ \\
\hline
\end{tabular}


The authors conclude that 'Results of LFS and TPLO are similar'.

\begin{tabular}{|c|c|}
\hline Limitations: & 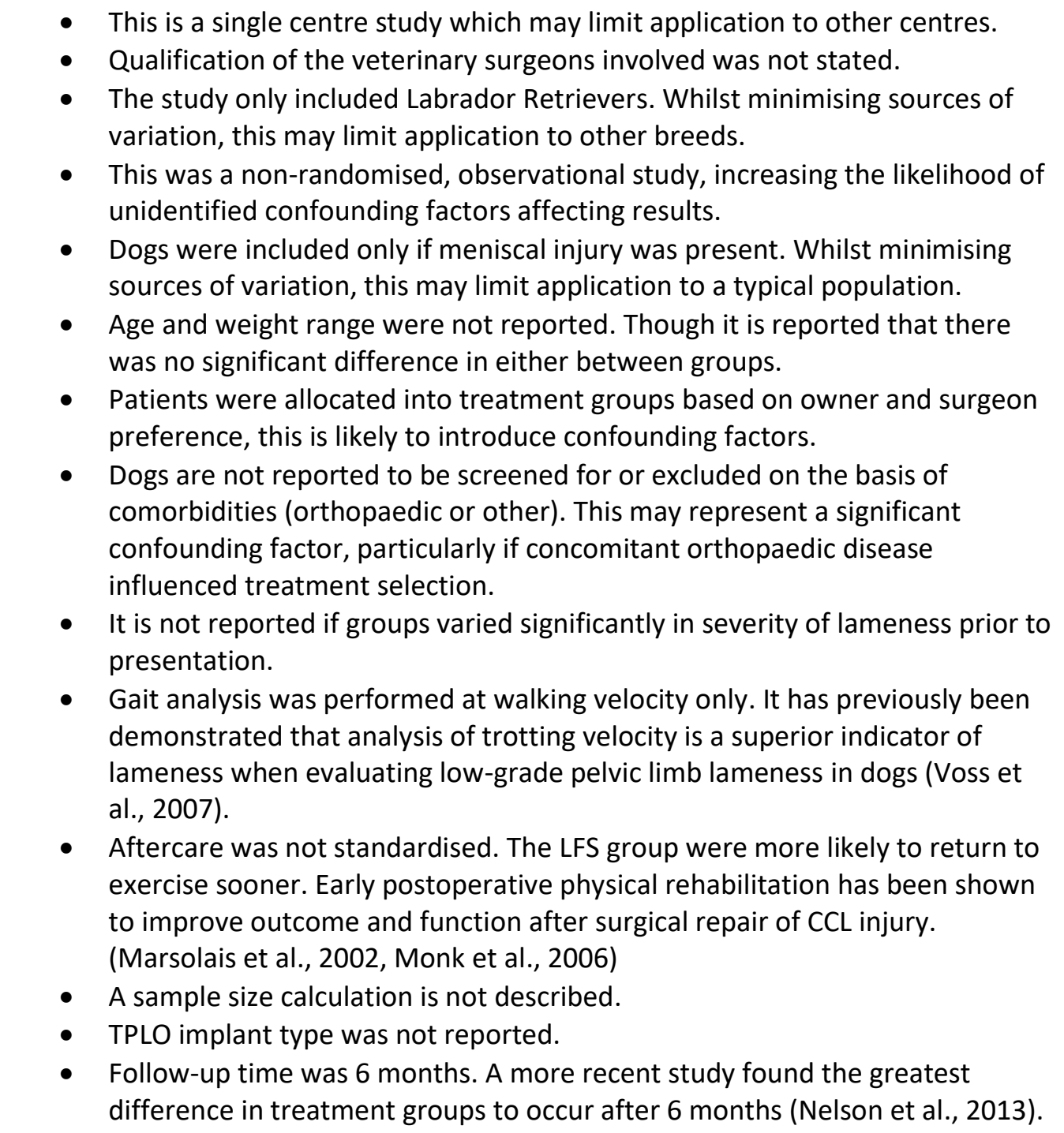 \\
\hline \multicolumn{2}{|l|}{ Lazar et al. (2005) } \\
\hline Population: & $\begin{array}{l}\text { Dogs weighing a minimum of } 22.7 \mathrm{~kg} \text {, with naturally occurring, CCL rupture (partial or } \\
\text { complete), with or without medial meniscal injury; treated surgically with either } \\
\text { placement of a LFS or TPLO. } \\
\text { Animals were excluded if they had received previous or subsequent stifle joint } \\
\text { surgery, or if there was evidence of other disease processes at surgery. }\end{array}$ \\
\hline Sample size: & 66 dogs (79 stifle joints \\
\hline $\begin{array}{r}\text { Intervention } \\
\text { details: }\end{array}$ & $\begin{array}{l}22 \text { patients ( } 27 \text { stifle joints) received LFS, } 44 \text { patients ( } 52 \text { stifle joints) received TPLO. } \\
\text { LFS was performed using two nylon leader sutures from the lateral fabella through } \\
\text { two holes drilled in the tibial tuberosity, followed by biceps fascia imbrication. TPLO } \\
\text { was performed as described by Slocum \& Slocum (1993). All procedures were } \\
\text { performed by board certified veterinary surgeons. } \\
\text { The medial meniscus status was evaluated by visual inspection for both LFS and TPLO } \\
\text { groups, and if damaged, partial medial meniscectomy was performed. If intact, either } \\
\text { no procedure was done or a medial meniscal release was performed where the } \\
\text { lateral attachment of the caudal horn of the medial meniscus was transected. }\end{array}$ \\
\hline
\end{tabular}




\begin{tabular}{|c|c|}
\hline & $\begin{array}{l}\text { Radiographs of each stifle joint were evaluated at preoperative and final } \\
\text { examinations. Radiographs were evaluated by the same two reviewers. A score was } \\
\text { determined by evaluating } 32 \text { specific radiographic features of OA. Structures } \\
\text { evaluated included the patella, femur, tibia, and surrounding soft tissues. Each } \\
\text { feature was graded 0-3 (absent, mild, moderate, or severe) to give a final score from } \\
0-96 . \\
\text { The difference between preoperative and final OA scores were subtracted and two } \\
\text { final score categories of a change less than or equal to five or over five were created. } \\
\text { Follow-up time was a minimum of } 12 \text { months between surgery and final examination. }\end{array}$ \\
\hline Study design: & Retrospective case series \\
\hline Outcome studied: & $\begin{array}{l}\text { - Radiography } \\
\circ \text { Mediolateral and either caudocranial or craniocaudal radiographic } \\
\text { projections were obtained at preoperative and final examinations }\end{array}$ \\
\hline $\begin{array}{r}\text { Main findings: } \\
\text { (relevant to PICO } \\
\text { question): }\end{array}$ & $\begin{array}{l}\text { There was no significant difference in OA scores between treatment groups at } \\
\text { defined time periods; however dogs with greater than six point change in pre and } \\
\text { postoperative scores were } 5.78 \text { times more likely to have been treated with a lateral } \\
\text { fabellotibial suture placement. }\end{array}$ \\
\hline Limitations: & 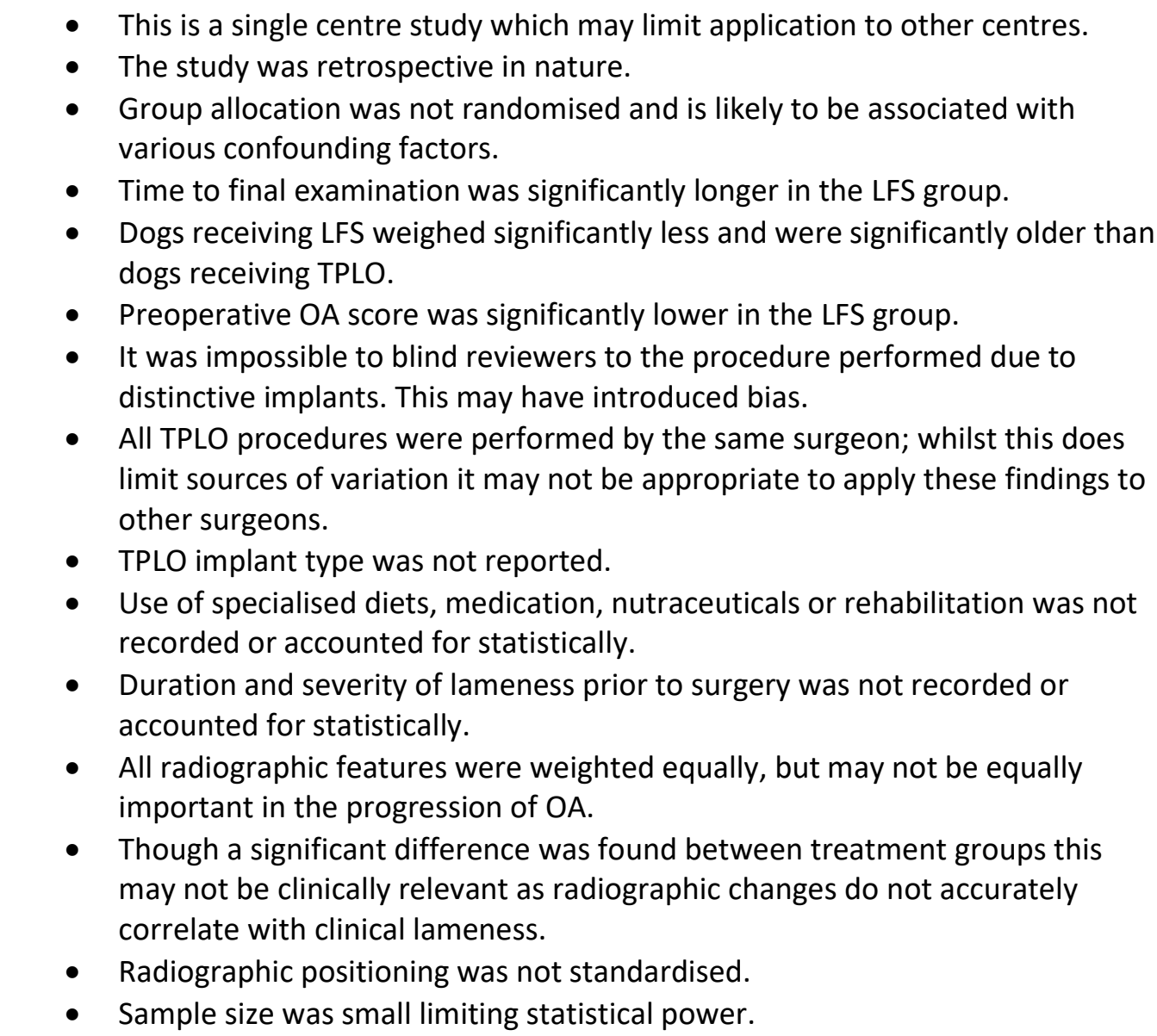 \\
\hline
\end{tabular}


Eight papers and one addendum were identified as relating to this question. The best quality evidence available was a randomised, blinded, controlled clinical trial (Gordon-Evans et al., 2013), this was a single centre study, with some variations in procedure and aftercare protocol.

Three non-randomised prospective observational studies were identified (Conzemius et al., 2005, Nelson et al., 2013, Au et al., 2010). In each case, treatment group allocation was based on owner preference.

The remaining papers were retrospective case series (Molsa et al., 2013, Frey et al., 2010, Lazar et al., 2005, Molsa at al., 2014).

The studies identified generally focused on one or more of the following categories; postoperative limb function, owner satisfaction, complication rates and radiographic evidence of $O A$.

Six studies looked at postoperative limb function (Molsa et al., 2013, Molsa et al., 2014, Gordon-Evans et al., 2013, Conzemius et al., 2005, Nelson et al., 2013, Au et al., 2010). One study (Molsa et al., 2013) found no significant difference between treatment groups as determined by non-validated, owner-completed questionnaire. Two studies (Conzemius 2005, Au et al., 2010) found no significant difference between treatment groups as determined by force plate analysis, however Au et al. (2010) reported a non-statistically significant increase in PVF in the TPLO group. One study (Molsa et al., 2014) found significantly less postoperative periarticular swelling and stifle joint crepitation in the TPLO group, but the clinical relevance of this was not clear. Two studies (Nelson et al., 2013, Gordon-Evans et al., 2013) found patients treated with TPLO had superior limb function to those treated with LFS, as determined by force plate analysis.

One study (Gordon-Evans et al., 2013) surveyed owner satisfaction after surgical repair of CCL rupture and reported that owner satisfaction at 12 months postoperatively was significantly higher in the TPLO group.

Three studies reported complication rates (Au et al., 2010, Frey et al., 2010, Gordon-Evans et al., 2013). The largest (Frey et al., 2010) reported the incidence of infected-inflamed wounds only and noted that 'TPLO was associated with a significantly higher rate of infection-inflammation'. The remaining two studies (Au et al., 2010, Gordon-Evans et al., 2013) reported the rate of all surgical complications and did not find a difference in rate between treatment groups.

Two studies looked at radiographic evidence of OA (Lazar et al., 2005, Au et al., 2010). The first (Lazar et al., 2005) found that dogs with larger OA score differences between preoperative and follow-up radiographs were 5.78 times more likely to have had LFS placement than TPLO. The second (Au et al., 2010) found no significant difference in OA scores between groups.

The conclusions made within the Clinical Bottom Line component of this knowledge summary are based on the following points:

- The best quality paper available reported a significant improvement in the kinematic results of the TPLO group compared to the LFS group at 6 and 12 months postoperatively (Gordon-Evans et al., 2013). This finding was supported by a second observational study (Nelson et al., 2013). Two studies of equivalent evidentiary quality (non-randomised, observational) found no statistical significance in force plate analysis between treatment groups. However the first study (Conzemius et al., 2005) reported follow-up to 6 months only, later studies reported the greatest difference in treatment groups to occur after 6 months (Nelson et al., 2013, Gordon-Evans et al., 2013). The second (Au et al., 2010) found a non-statistically significant improvement in the TPLO group compared with the LFS group between 6 and 24 months postoperatively. Both of these studies (Conzemius et al., 2005, Au et al., 2010) assessed patients at walking velocity only, it has been reported that trotting velocity is more sensitive for detection of low grade pelvic lameness (Voss et al., 2007).

- Only one paper - a retrospective case series - reported an improvement in any outcome (complication rate) after LFS compared to TPLO (Frey et al., 2010), however wounds were classified as infected- 
inflamed on the basis of retrospective medical record review and the clinical relevance of findings (i.e. if patients required additional treatment) was not clear. Two other papers recorded complication rates, Au et al. (2010) reported that there was no significant difference between groups and GordonEvans et al. (2013) reported that the complication rates of both procedures were similar.

- Only one study (Frey et al., 2010) found a difference in complication rates between procedures.

- Only one paper (Gordon-Evans et al., 2013) looked at owner satisfaction as an outcome and found a significant improvement in the TPLO group compared to the LFS group at 12 months postoperatively.

However extrapolating the data reported here to make recommendations for changes in current clinical practice does have several inherent problems:

Firstly, all procedures reported were performed at referral centres. Thus it may not be correct to assume this data can be extrapolated to LFS and TPLO performed in general practice, or where the choice is between LFS performed in a first-opinion practice, and referral to a specialist centre for a TPLO procedure.

Thirdly, this summary discusses the impact of procedure selection on a limited number of outcomes. Other factors such as cost, hospitalisation duration, aftercare and local availability of services are not considered here, however are expected to vary between procedures and accordingly influence client choice.

In conclusion this knowledge summary suggests that TPLO results in superior limb function and owner satisfaction compared to placement of a LFS; however further research - including multi-centre, randomised, controlled clinical trials and investigation of the outcomes of surgery performed in general practice - is indicated.

\section{Methodology Section}

\begin{tabular}{|c|c|}
\hline \multicolumn{2}{|l|}{ Search Strategy } \\
\hline $\begin{array}{r}\text { Databases searched and dates } \\
\text { covered: }\end{array}$ & $\begin{array}{l}\text { CAB Abstracts on OVID Platform 1973-Week } 202018 \\
\text { PubMed accessed via the NCBI website (1910-2018) }\end{array}$ \\
\hline Search terms: & $\begin{array}{l}\text { PubMed: } \\
\text { (Canine OR canines OR dog OR dogs OR bitch OR bitches OR canis) } \\
\text { AND } \\
\text { (Cranial OR anterior) } \\
\text { AND } \\
\text { Cruciate } \\
\text { AND } \\
\text { (Osteotomy OR TPLO OR tibial plateau level) } \\
\text { AND } \\
\text { (Lateral OR fabellar OR fabellotibial OR tibiofabella OR extracapsular } \\
\text { OR extra-capsular) } \\
\text { CAB Abstracts: } \\
\text { Canine OR canines OR dog OR dogs OR bitch OR bitches OR canis) } \\
\text { AND } \\
\text { (Cranial OR anterior) } \\
\text { AND } \\
\text { Cruciate } \\
\text { AND } \\
\text { (Osteotomy OR TPLO OR tibial plateau level) } \\
\text { AND } \\
\text { (Lateral OR fabellar OR fabellotibial OR tibiofabella OR extracapsular }\end{array}$ \\
\hline
\end{tabular}




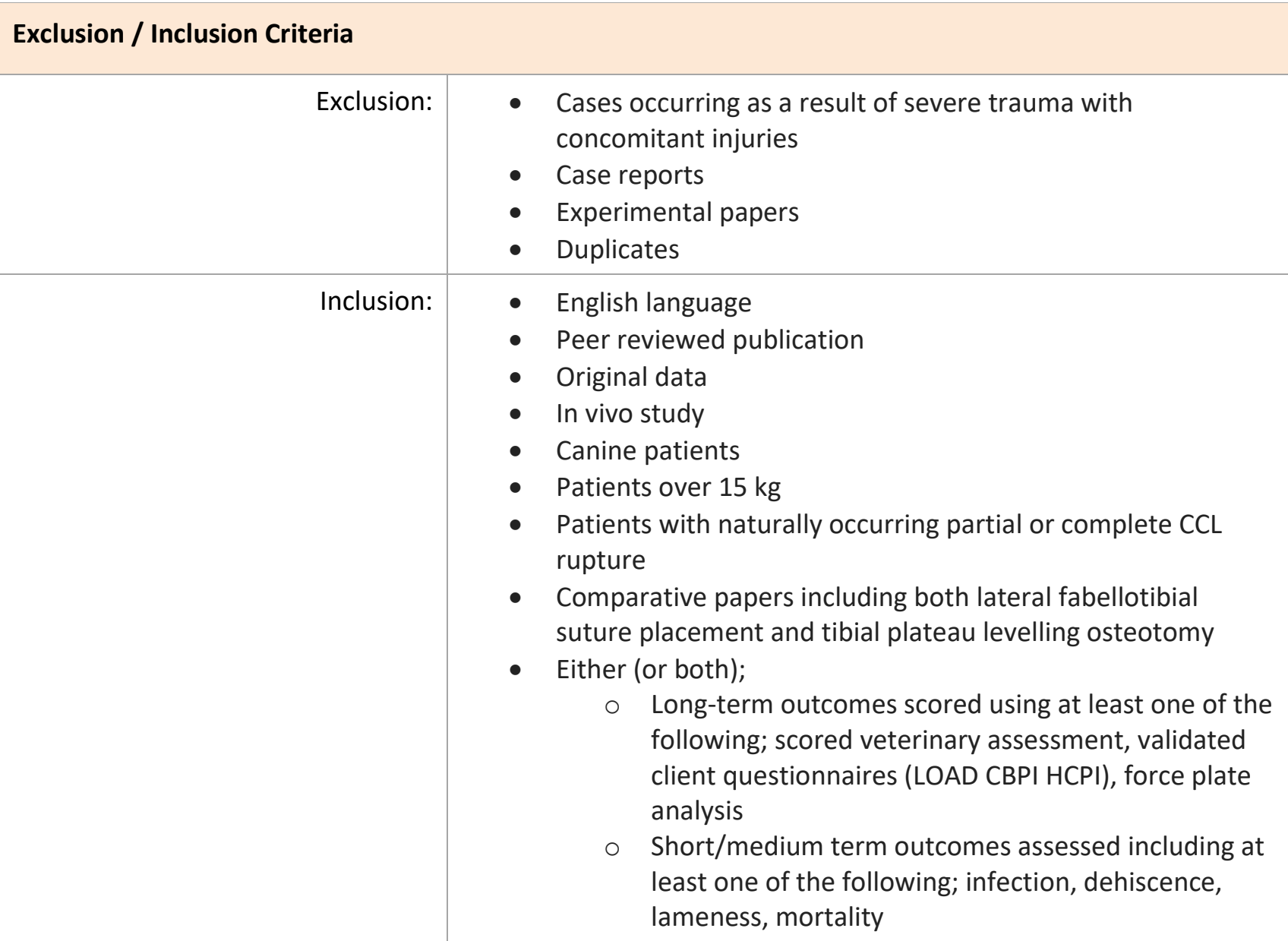

\section{Search Outcome}

\begin{tabular}{|c|c|c|c|c|c|c|c|c|c|c|}
\hline Database & $\begin{array}{l}\text { Number } \\
\text { of results }\end{array}$ & $\begin{array}{l}\text { Excluded } \\
\text { - non- } \\
\text { canine } \\
\text { patients }\end{array}$ & $\begin{array}{l}\text { Excluded- } \\
\text { artificially } \\
\text { induced } \\
\quad \mathrm{CCL} \\
\text { rupture }\end{array}$ & $\begin{array}{l}\text { Excluded } \\
\text { - no } \\
\text { patients } \\
\text { over } 15 \mathrm{~kg}\end{array}$ & $\begin{array}{l}\text { Excluded } \\
\text { - non- } \\
\text { English } \\
\text { language }\end{array}$ & $\begin{array}{c}\text { Excluded } \\
\text { - no } \\
\text { original } \\
\text { data }\end{array}$ & $\begin{array}{c}\text { Excluded } \\
\text { - not in } \\
\text { vivo }\end{array}$ & $\begin{array}{l}\text { Excluded - } \\
\text { did not } \\
\text { include } \\
\text { both TPLO } \\
\text { and LFS }\end{array}$ & $\begin{array}{c}\text { Excluded } \\
\text { - non- } \\
\text { comparati } \\
\text { ve }\end{array}$ & $\begin{array}{c}\text { Total } \\
\text { relevant } \\
\text { papers }\end{array}$ \\
\hline $\begin{array}{l}\text { CAB } \\
\text { Abstracts }\end{array}$ & 63 & 0 & 1 & 0 & 13 & 5 & 9 & 23 & 3 & 9 \\
\hline $\begin{array}{l}\text { NCBI } \\
\text { PubMed }\end{array}$ & 52 & 1 & 1 & 1 & 0 & 2 & 7 & 28 & 4 & 8 \\
\hline
\end{tabular}


The authors declare no conflict of interest.

\section{REFERENCES}

1. Au, K., Gordon-Evans, W., Dunning, D., O’Dell-Anderson, K., Knap, K., Griffon, D., \& Johnson, A. (2010) Comparison of short- and long-term function and radiographic osteoarthrosis in dogs after postoperative physical rehabilitation and tibial plateau levelling osteotomy or lateral fabellar suture stabilization. Veterinary Surgery; 39: 173-180. DOI: https://doi.org/10.1111/i.1532-950X.2009.00628.x

2. Conzemius, M., Evans, R., Faulkner Besancon, M., Gordon, W., Horstman, C., Hoefle, W., Nieves, M., \& Wagner, S. (2005) Effect of surgical technique on limb function after surgery for rupture of the cranial cruciate ligament in dogs. JAVMA; 226(2): 232-236. DOI: https://doi.org/10.2460/javma.2005.226.232

3. Cox, J., Nye, C., Schaefer, W., \& Woodstein, I. (1975). The degenerative effect of partial and total resection of the medial meniscus in dogs' knees. Clin Orthop; 109: 178-181. DOI: 10.1097/00003086$\underline{197506000-00026}$

4. Frey, T., Hoelzer, M., Scavelli, T., Fulcher, R., \& Bastian, R. (2010) Risk factors for surgical site infectioninflammation in dogs undergoing surgery for rupture of the cranial cruciate ligatment: 902 cases (2005-2006). JAVMA; 236 (1): 88-94. DOI: https://doi.org/10.2460/javma.236.1.88

5. Gordon-Evans, W. (2016) Clinical effect of tibial plateau leveling osteotomy compared to lateral fabellar suture in dogs. Veterinary Evidence; 1(3): 44. DOI: http://dx.doi.org/10.18849/ve.v1i3.44

6. Gordon-Evans, W., Griffon, D., Bubb, C., Knap, K., Sullivan, M., \& Evans, R. (2013) Comparison of lateral fabellar suture and tibial plateau levelling osteotomy techniques for treatment of dogs with cranial cruciate ligament disease. JAVMA; 243 (5): 675-680. DOI: https://doi.org/10.2460/javma.243.5.675

7. Hielm-Björkman, A., Rita, H., Tulamo, R. (2009) Psychometric testing of the Helsinki chronic pain index by completion of a questionnaire in Finnish by owners of dogs with chronic signs of pain caused by osteoarthritis. American Journal of Veterinary Research; 70: 727-734.

DOI: https://doi.org/10.2460/ajvr.70.6.727

8. Lazar, T., Berry, C., Dehaan, J., Peck, J., \& Correa, M. (2005) Long term radiographic comparison of tibial plateu levelling osteotomy versus extracapsular stabilization for cranial cruciate ligament rupture in the dog. Veterinary Surgery; 34: 133-141. DOI: https://doi.org/10.1111/j.1532950X.2005.00021.x

9. Marsolais, G., Dvorak, G., \& Conzemius, M. (2002) Effects of postoperative rehabilitation on limb function after CCL repair in dogs. JAVMA; 220: 1325-1330. DOI: 10.2460/javma.2002.220.1325

10. Molsa, S., Hielm-Bjorkman, A., \& Laitinen-Vapaavuori, O. (2013) Use of an owner questionnaire to evaluate long-term surgical outcome and chronic pain after cranial cruciate ligament repair in dogs: 253 cases (2004-2006). JAVMA; 243(5): 689-695. DOI: https://doi.org/10.2460/javma.243.5.689

11. Molsa, S., Hyytiainen, H., Hielm-Bjorkman, A., \& Laitinen-Vapaavuori, O. (2014) Long-term function 
outcome after surgical repair of cranial cruciate ligament disease in dogs. BMC Veterinary Research; 10: 266. DOI: https://doi.org/10.1186/s12917-014-0266-8

12. Monk, M., Preston, C., \& McGowan, C. (2006) Effects of early intensive postoperative physiotherapy on limb function after TPLO in dogs with deficiency of the cranial cruciate ligament. Am J Vet Res; 67: 529-536. DOI: https://doi.org/10.2460/ajvr.67.3.529

13. Nelson, S., Krotscheck, U., Rawlinson, J., Todhunter, R., Zhang, Z., \& Mohammed, H. (2013) Long-term functional outcome of tibial plateau levelling osteotomy versus extracapsular repair in a heterogenous population of dogs. Veterinary Surgery; 42: 38-50. DOI: https://doi.org/10.1111/j.1532950X.2012.01052.x

14. Slocum, B., \& Slocum, T. (1993) Tibial plateau levelling osteotomy for repair of cranial cruciate ligament rupture in the canine. Veterinary Clinics of North America; 23:777-795.

DOI: https://doi.org/10.1016/S0195-5616(93)50082-7

15. Solano, M., Danielski, A., Kovach, K., Fitzpatrick, N., \& Farell, M. (2015) Locking plate and screw fixation after Tibial Plateau Leveling Osteotomy reduces postoperative infection rate in dogs over $50 \mathrm{~kg}$. Veterinary Surgery; 44: 59-64. DOI: https://doi.org/10.1111/j.1532-950X.2014.12150.x

16. Vasseur, B., Berry, C. (1991) Progression of stifle osteoarthrosis following reconstruction of the cranial cruciate ligament in 21 dogs. JAAHA; 28: 129-136.

17. Voss, K., Imhof, J., Kaestner, S., \&Montavon, P. (2007) Force plate gait analysis at the walk and trot in dogs with low-grade hindlimb lameness. VCOT; 20:299-304. DOI: 10.1160/VCOT-07-01-0008 


\section{EVIIDEFeE

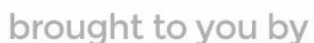 \\ RCVS KNOWLEDGE}

\section{Intellectual Property Rights}

Authors of Knowledge Summaries submitted to RCVS Knowledge for publication will retain copyright in their work, and will be required to grant RCVS Knowledge a non-exclusive license of the rights of copyright in the materials including but not limited to the right to publish, re-

publish, transmit, sell, distribute and otherwise use the materials in all languages and all media throughout the world, and to license or permit others to do so.

\section{Disclaimer}

Knowledge Summaries are a peer-reviewed article type which aims to answer a clinical question based on the best available current evidence. It does not override the responsibility

of the practitioner. Informed decisions should be made by considering such factors as individual clinical expertise and judgement along with patient's circumstances and owners' values. Knowledge Summaries are a resource to help inform and any opinions expressed within the Knowledge Summaries are the author's own and do not necessarily reflect the view of the RCVS Knowledge. Authors are responsible for the accuracy of the content. While the

Editor and Publisher believe that all content herein are in accord with current recommendations and practice at the time of publication, they accept no legal responsibility

for any errors or omissions, and make no warranty, express or implied, with respect to material contained within.

For further information please refer to our Terms of Use.

RCVS Knowledge is the independent charity associated with the Royal College of Veterinary Surgeons (RCVS). Our ambition is to become a global intermediary for evidence based veterinary knowledge by providing access to information

that is of immediate value to practicing veterinary professionals and directly contributes to evidence based clinical decision-making.

https://www.veterinaryevidence.org/

RCVS Knowledge is a registered Charity No. 230886.

Registered as a Company limited by guarantee in England and Wales No. 598443.

Registered Office: Belgravia House, 62-64 Horseferry Road, London SW1P 2AF

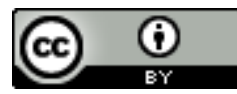

This work is licensed under a Creative Commons Attribution 4.0 International License 